\title{
Microbial community structure and the relationship with soil carbon and nitrogen in an original Korean pine forest of Changbai Mountain, China
}

Minghui Liu' ${ }^{1}$ Xin Sui ${ }^{2}$, Yanbo Hu${ }^{3}$ and Fujuan Feng ${ }^{1 *}$ (I)

\begin{abstract}
Background: The broad-leaved Korean pine mixed forest is an important and typical component of a global temperate forest. Soil microbes are the main driver of biogeochemical cycling in this forest ecosystem and have complex interactions with carbon $(\mathrm{C})$ and nitrogen $(\mathrm{N})$ components in the soil.

Results: We investigated the vertical soil microbial community structure in a primary Korean pine-broadleaved mixed forest in Changbai Mountain (from 699 to $1177 \mathrm{~m}$ ) and analyzed the relationship between the microbial community and both $\mathrm{C}$ and $\mathrm{N}$ components in the soil. The results showed that the total phospholipid fatty acid (PLFA) of soil microbes and Gram-negative bacteria (G-), Gram-positive bacteria (G+), fungi (F), arbuscular mycorrhizal fungi (AMF), and Actinomycetes varied significantly $(p<0.05)$ at different sites (elevations). The ratio of fungal PLFAs to bacterial PLFAs (F/B) was higher at site $\mathrm{H} 1$, and $\mathrm{H} 2$. The relationship between microbial community composition and geographic distance did not show a distance-decay pattern. The coefficients of variation for bacteria were maximum among different sites (elevations). Total soil organic carbon (TOC), total nitrogen (TN), soil water content $(\mathrm{W})$, and the ratio of breast-height basal area of coniferous trees to that of broad-leaved tree species (RBA) were the main contributors to the variation observed in each subgroup of microbial PLFAs. The structure equation model showed that TOC had a significant direct effect on bacterial biomass and an indirect effect upon bacterial and fungal biomass via soil readily oxidized organic carbon (ROC). No significant relationship was observed between soil $\mathrm{N}$ fraction and the biomass of fungi and bacteria.
\end{abstract}

Conclusion: The total PLFAs (tPLFA) and PLFAs of soil microbes, including G-, G+, F, AMF, and Actinomycetes, were significantly affected by elevation. Bacteria were more sensitive to changes in elevation than other microbes. Environmental heterogeneity was the main factor affecting the geographical distribution pattern of microbial community structure. TOC, TN, W and RBA were the main driving factors for the change in soil microbial biomass. $C$ fraction was the main factor affecting the biomass of fungi and bacteria and ROC was one of the main sources of the microbial-derived $\mathrm{C}$ pool.

Keywords: Original Korean pine forest, Soil microbial community, Biogeographic distribution, Distance-decay relationship, Soil carbon and nitrogen, Structural equation model

\footnotetext{
* Correspondence: ffj9018@sina.com

${ }^{1}$ College of Life Science, Northeast Forestry University, Harbin 150040, China

Full list of author information is available at the end of the article
}

(c) The Author(s). 2019 Open Access This article is distributed under the terms of the Creative Commons Attribution 4.0 International License (http://creativecommons.org/licenses/by/4.0/), which permits unrestricted use, distribution, and reproduction in any medium, provided you give appropriate credit to the original author(s) and the source, provide a link to the Creative Commons license, and indicate if changes were made. The Creative Commons Public Domain Dedication waiver (http://creativecommons.org/publicdomain/zero/1.0/) applies to the data made available in this article, unless otherwise stated. 


\section{Background}

Soil microorganisms, as an important component in a forest ecosystem, are sensitive to environmental change and represent the key factor affecting the decomposition of soil organic matter, nutrient cycling, and biogeochemical cycles $[1,2]$. Studying the biogeochemical distribution of soil microbial communities not only helps to explore the ecological process more deeply, but also has important implications for the protection of microbial resources and the management of terrestrial forest ecosystems [3]. And increasing number of studies are showing that the composition, abundance and/or diversity of microbial communities show a certain spatial distribution pattern with some environmental variables. Nevertheless, the study of microbial biogeography is still very weak compared with that of macroorganisms (animals and plants) [4]. Whether microbial biogeographic distribution exits at different spatial scales is still controversial, particularly in terms of the distribution pattern of microbial communities along an elevation.

Soil microorganisms are the main driver for the biochemical cycle [5, 6]. Differences in spatial distribution of the soil microbial community can affect the turnover of soil carbon $(\mathrm{C})$ and nitrogen $(\mathrm{N})$ through its interaction with vegetation and various soil properties $[7,8]$. Conversely, as important biogenic factors, the gradient effects of $\mathrm{C}$ and $\mathrm{N}$ in the soil can also cause significant effects upon the microbial community structure [9]. Obviously, the interactions between soil microorganisms and the $\mathrm{C}$ and $\mathrm{N}$ fractions are complex. Developing a deep understanding of these interactions is crucial for the sequestration and stability of $\mathrm{C}$ and $\mathrm{N}$ in the soil [8].

The broad-leaved Korean pine mixed forest (Pinus koraiens is as an edificator), is an important and typical component of a global temperate forest and recognized as a sensitive zone in terms of global climate change. Compared with temperate forests at the same latitude in Europe and America, the Korean pine forest in Changbai Mountain is famous for its complex structure, unique composition, and rich biological diversity. This Korean pine forest is also an important $\mathrm{C}$ sink for atmospheric $\mathrm{CO}_{2}$ [10], with an annual net ecosystem $\mathrm{C}$ exchange of $191.3 \mathrm{~g} / \mathrm{m}^{2}$ [11]. Changbai Mountain is one of the most intact regions in the global natural ecosystem [12] and exerts great significance in regulating regional climate and maintaining regional land ecological balance. Thus, Changbai Mountain is an ideal zone with which to study the positive and negative feedback mechanisms exhibited by temperate forests upon global climate change. In particular, Changbai Mountain is one of the two main central distribution areas of natural Korean pine, where the original Korean pine broad-leaved forest remains intact at elevations of 700-1300 m.

Environmental factors (such as temperature, precipitation, and soil physicochemical properties) and the composition of vegetation vary with elevation gradient $[2,13,14]$. Changes in these factors, and their interaction, will directly, or indirectly, affect the spatial distribution patterns of soil microbial community along an elevational gradient. Our previous studies have found that soil bacterial and fungal community structures obviously varied along different elevation gradients, especially bacteria and fungi of soil showed different response by soil physicochemical properties $[3,15]$. However, the distribution patterns of overall microbial taxa in this area still unknown. Investigating the distribution pattern of soil microorganisms over an elevational gradient can provide data support and a realistic basis for scientifically evaluating the biogeographical distribution of soil microorganisms [16].

In this study, we selected sites at the primary Korean pine broad-leaved forest on the northern slope of Changbai Mountain (from 699 to $1177 \mathrm{~m}$ ) and sampled two surface soil (at depths of $0-10 \mathrm{~cm}$ and $10-20 \mathrm{~cm}$ ). The aims of this study were: (1) to study the spatial distribution patterns of the soil microbial community at different elevations and explore the mechanism underlying observed differences, and (2) to analyze the relationship between the characteristics of the soil microbial community and $\mathrm{C}, \mathrm{N}$ components in the soil. In carrying out this study, we expected to reveal the mechanisms of interaction between soil microorganisms and the $\mathrm{C}, \mathrm{N}$ sequestration in the Korean pine forest ecosystem.

\section{Results}

\section{Soil microbial community structure}

At a soil depth of $0-10 \mathrm{~cm}$, soil microbial biomass carbon $(\mathrm{MBC})$, microbial biomass nitrogen $(\mathrm{MBN})$ and total PLFAs (tPLFA), Gram-negative bacteria (G-), Gram-positive bacteria $(\mathrm{G}+)$, fungi (F), arbuscular mycorrhizal fungi (AMF), and Actinomycetes were significantly affected by elevation gradients. All the indices were significantly different when compared across different gradients $(p<0.05)$ (Fig. 1, Fig. 2), and showed similar trends as elevation increased. All indices were highest at site $\mathrm{H} 4$ and lowest at site H5. In addition, The ratio of fungal PLFAs to bacterial PLFAs $(\mathrm{F} / \mathrm{B})$ ratios value were also significantly different at different sites $(p<0.05)$; the maximum values $(0.062)$ occurred at site $\mathrm{H} 1$ while the minimum values $(0.052)$ occurred at site H4 (Fig. 2).

At a soil depth of $10-20 \mathrm{~cm}, \mathrm{MBC}, \mathrm{MBN}$, and PLFAs content, including G-, G+, F, AMF, and Actinomycetes, were significantly different at different sites. The maximum and lowest values occurred at sites $\mathrm{H} 1$ and $\mathrm{H} 5$, respectively (Fig. 1, Fig. 2). F/B ratio was both significantly different at different sites $(p<0.05)$; increasing first and then decreasing as elevation increased; the highest values were recorded at site $\mathrm{H} 2$ (Fig. 2). 


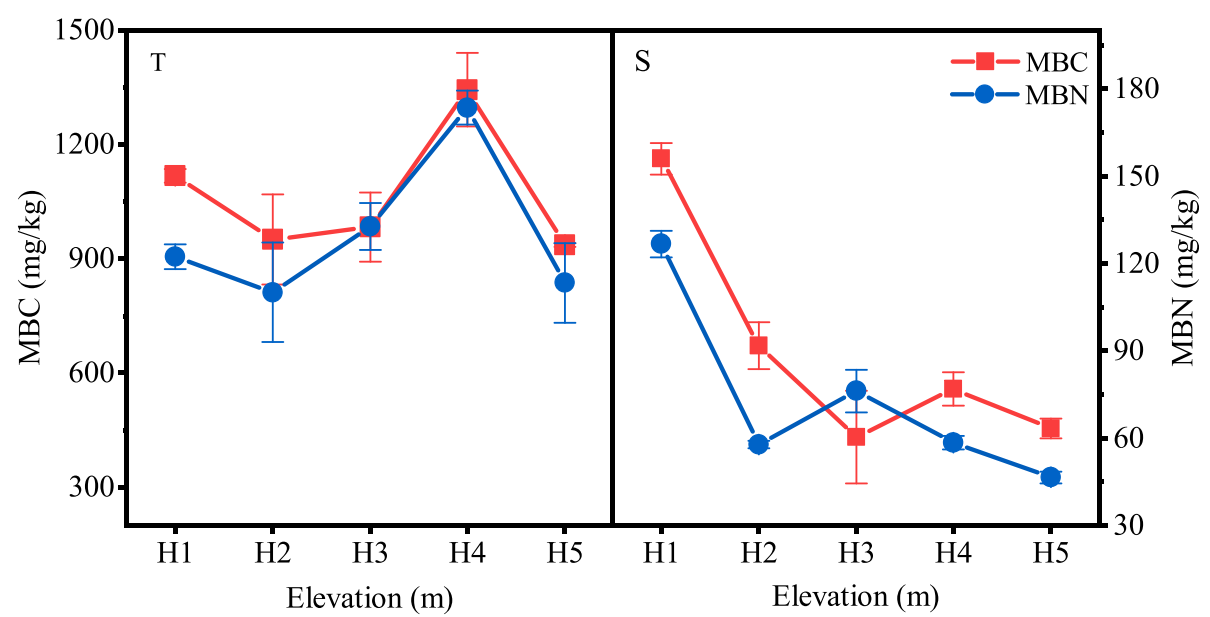

Fig. 1 Soil microbial biomass at different elevations. MBC, microbial biomass carbon; MBN, microbial biomass nitrogen. T and S represent depths of $0-10 \mathrm{~cm}$ and $10-20 \mathrm{~cm}$ respectively

\section{Biogeographical distribution of microbial communities} Nonmetric Multidimensional Scaling plots showed that the groups of soil microorganisms at each site were clearly clustered together (Fig. 3). The relationship between microbial community composition and geographic distance did not show a distance-decay pattern $(p>0.05)$ (Fig. 4). A partial Mantel Test showed that environmental soil factors were the controlling factors affecting microbial community composition (Table 1).

The coefficient of variation $(\mathrm{CV})$ represents the degree of dispersion between data, thus reflecting the spatial differentiation of microbial groups at different elevations (sites). CV decreased in the following order: G->Actinomycetes $>$ AMF $>$ G+ $>$ F at a soil depth of $0-10 \mathrm{~cm}$ and $\mathrm{G}+>$ Actinomycetes $>$ G- $>$ AMF $>F$ at a soil depth of $10-20 \mathrm{~cm}$ (Table 2). Clearly, therefore, the spatial diversity of bacteria was greater than that of fungi.

\section{Controls on soil microbial community}

Detrended correspondence analysis of the PLFAs showed that the length of the first sort axis was less than 3. Therefore, the data was analyzed by redundancy analysis based on the linear model. Then we analyzed the effects of soil physicochemical factors that might affect the microbial community, including total soil organic carbon (TOC), total nitrogen (TN), soil water content $(\mathrm{W})$, temperature, $\mathrm{pH}$, available nitrogen (AN), available pholsophy (AP), available K (AK), clay, silt, and sand, and the vegetation community, including the breastheight basal area of coniferous tree species per unit area (CBA), breast-height basal area of broad-leaved tree species per unit area (BLBA) and ratio of breast-height basal area of coniferous tree height to that of broad-leaved tree species (RBA), upon PLFAs of soil microbes. TOC, RBA, W, BLBA, TN, temperature were selected based on Stepwise Algorithm for RDA. As shown in Fig. 5, the
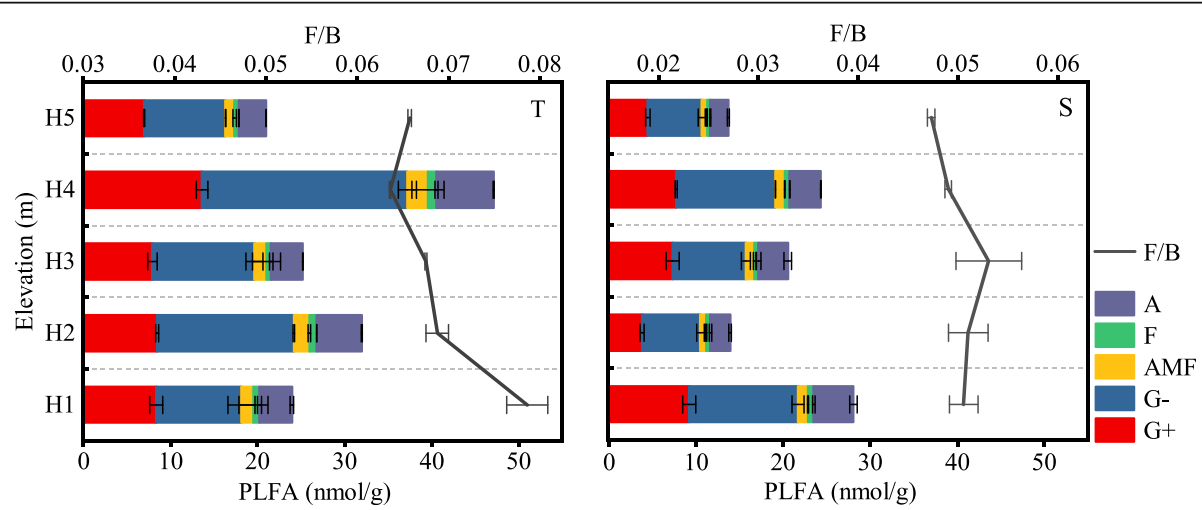

Fig. 2 Soil microbial PLFA and Fungal/Bacterial PLFAs ratio under different elevations. T and $S$ represent depths of 0-10 cm and $10-20 \mathrm{~cm}$ respectively 


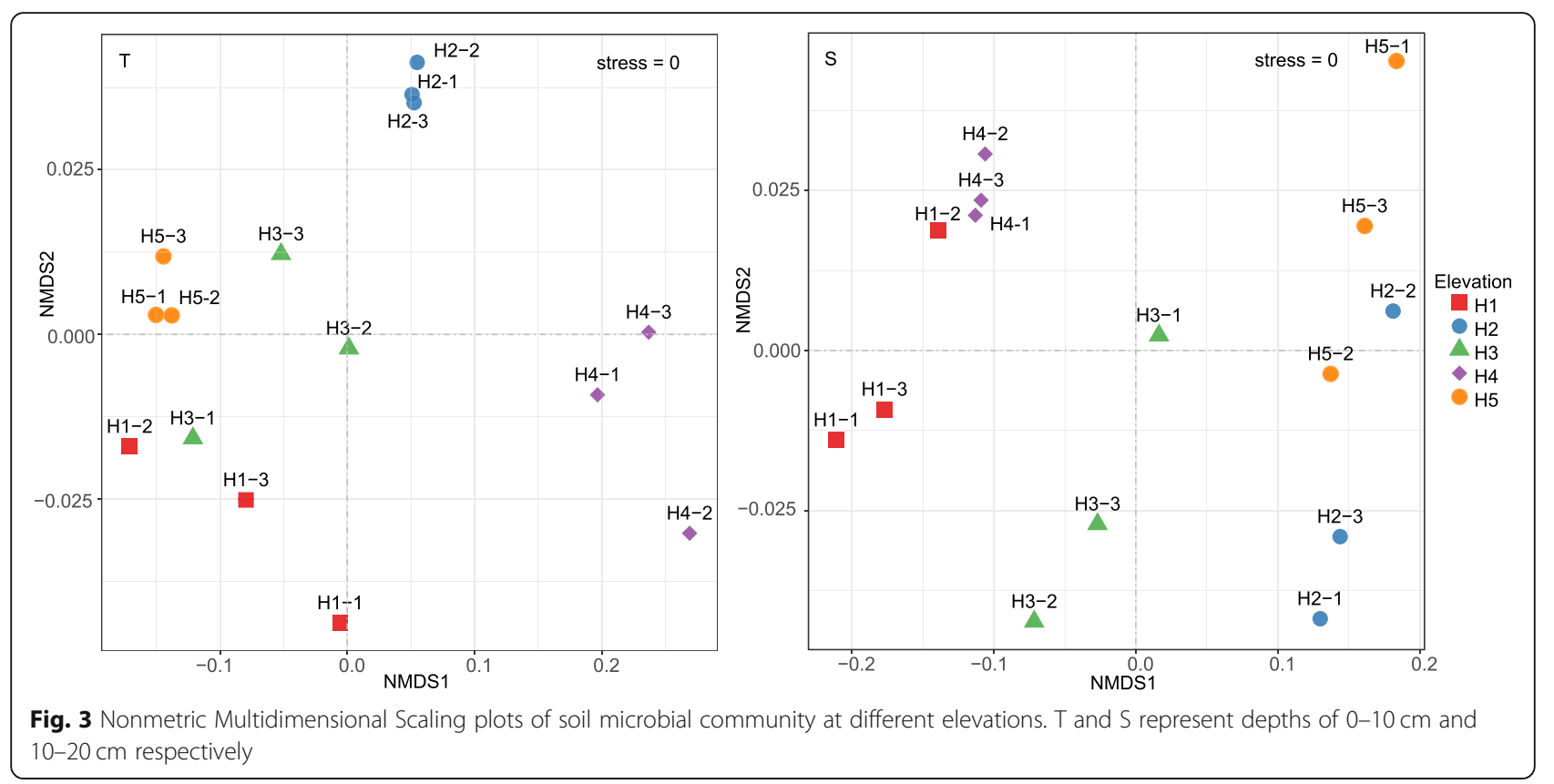

first two axes of the RDA accounted for $86.64 \%$ of the variance in soil microbial community, with the first axis accounting for $72.65 \%$ of the variance. TOC $(P<0.001$, $\left.\mathrm{R}^{2}=0.9141\right), \mathrm{TN}\left(P<0.001, \mathrm{R}^{2}=0.8435\right), \mathrm{W}(P<0.001$, $\left.\mathrm{R}^{2}=0.7081\right)$, and RBA $\left(P=0.003, \mathrm{R}^{2}=0.3663\right)$ were the significant contributors to the variation observed in each subgroup of microbial PLFAs.

\section{Soil carbon and nitrogen}

Our analysis showed that soil TOC, soil readily oxidized organic carbon (ROC), $\mathrm{TN}, \mathrm{NH}_{4}{ }^{+}-\mathrm{N}$, and $\mathrm{NO}_{3}{ }^{-}-\mathrm{N}$ changed significantly across different sites and soil layers $(p<0.01)$. At a soil depth of $0-10 \mathrm{~cm}, \mathrm{TOC}, \mathrm{ROC}, \mathrm{TN}$, and $\mathrm{NH}_{4}{ }^{+}-\mathrm{N}$ showed similar trends of variation with increasing elevation; with maximum values at site $\mathrm{H} 4$ and minimum values at site $\mathrm{H} 5$. The $\mathrm{NO}_{3}{ }^{-}-\mathrm{N}$ concentration at a soil depth of $0-10 \mathrm{~cm}$ showed an "N"-shape changing pattern as elevation increased, with the highest value at site $\mathrm{H} 2$ and the lowest value at site $\mathrm{H} 4$, respectively (Fig. 6). At a soil depth of $10-20 \mathrm{~cm}$, TOC, ROC, $\mathrm{TN}$, and $\mathrm{NH}_{4}{ }^{+}-\mathrm{N}$ showed the highest values at site $\mathrm{H} 1$, with a decline with increasing elevation. The value of $\mathrm{NO}_{3}{ }^{-}-\mathrm{N}$ was the lowest at site $\mathrm{H} 3$, showing a "V"-shape changing pattern (Fig. 6).

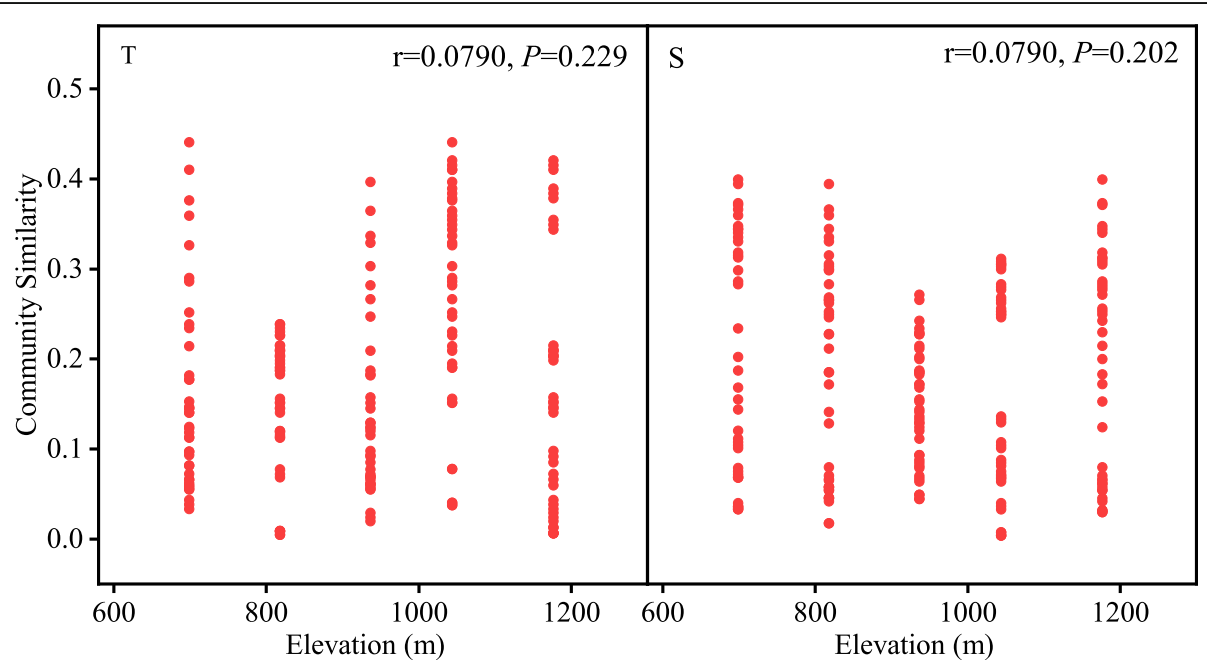

Fig. 4 Distance-decay relationships of similarity among soil microbial communities at different elevations. T and $\mathrm{S}$ represent depths of $0-10 \mathrm{~cm}$ and $10-20 \mathrm{~cm}$, respectively 
Table 1 Relationships among dissimilarities of the microbial communities and environmental factors. Geographic distance was determined by Partial Mantel tests

\begin{tabular}{lllll}
\hline Soil layer & Variables & Control for & Mantel statistics $r$ & $p$ \\
\hline $\mathrm{T}$ & Environmental factors & Geographic distance & 0.7883 & 0.001 \\
& Geographic distance & Environmental factors & 0.0898 & 0.199 \\
$\mathrm{~S}$ & Environmental factors & Geographic distance & 0.6038 & 0.001 \\
& Geographic distance & Environmental factors & 0.1950 & 0.063 \\
\hline
\end{tabular}

\section{Relationship between soil microbial community structure and soil $\mathrm{C}$ and $\mathrm{N}$}

The equation obtained by multiple linear regression analysis satisfied the F test $(p<0.05)$ (Table 3$)$. Both total bacteria $(\mathrm{tB})$ and total fungi $(\mathrm{tF})$ were positively correlated with ROC $(p<0.05)$, which explained $78.0 \%$ and $79.0 \%$ of the changes of $\mathrm{tB}$ and $\mathrm{tF}$, respectively. Multivariate linear regression analysis neglected the interaction between variables; in order to reflect the complex relationship within the variables more comprehensively and thoroughly, the structure equation model was used to establish the relationship between soil microbial groups and soil $\mathrm{C}$ and $\mathrm{N}$ fraction. After several fittings and revisions, we obtained the model shown in Fig. 7; the path coefficient was shown in Table 4. According to the fitting index, the model fitted well with the data. The structure equation model revealed that soil ROC had a significant correlation with the $\mathrm{tB}$ and $\mathrm{tF}(p<0.01, p<0.001)$, with a path coefficient of 0.49 and 0.89 , respectively. The effects of soil TOC on $\mathrm{tB}$ were significant $(p<0.01)$, and there were indirect significant effects upon $\mathrm{tB}$ and $\mathrm{tF}$ via ROC, the indirect effect coefficients of which were 0.88 and 0.87 , respectively. In addition, TOC had a significant negative correlation with $\mathrm{F} / \mathrm{B} \quad(p<0.05)$. There was no significant correlation between soil TN and microbial biomass (tB, tF) $(p>0.05)$, but a significant positive correlation was observed between TN and F/B $(p<0.05, p<0.001)$, with a path coefficient of 1.00 .

\section{Discussion}

\section{Soil microbial community structure}

Soil microbial tPLFA and MBC were significantly different when elevations were compared in a primitive Korean pine forest of Changbai mountain $(p<0.05)$, with a similar trend across elevations. The significant positive correlation between tPLFA and MBC $\left(\mathrm{R}^{2}=0.4912, p<\right.$ 0.05) [Additional file 2] indicated that tPLFA was a reliable indicator of biomass [17, 18]. Soil microbial tPLFA and G-, G+, F, AMF, Actinomycetes, and PLFAs showed a similar trend with changing elevation, and the content of each sub-group was significantly affected by a change in elevation $(p<0.05)$. The maximum values of the PLFA of each sub-group were found at sites $\mathrm{H} 4$ and $\mathrm{H} 1$, indicating that the microbial biomass-total PLFAs and each sub-group were the highest in the areas.

F/B, estimated by fungal PLFA and bacterial PLFA, can demonstrate timely responses to environmental changes such as aboveground vegetation and nutrient availability $[2,19]$. In the present study, the value of F/B decreased significantly when the elevation increased to $1000 \mathrm{~m}$ (Fig. 2), indicating that the soil conditions at a higher elevation were more favorable for the survival of bacteria. Compared to fungi, bacteria prefer nutrientrich conditions [20] which was also proven in this study through contrary vertical variations of soil $\mathrm{C}$ and $\mathrm{N}$ (Fig. 6) and F/B (Fig. 2). The F/B ratio can characterize the soil $\mathrm{C}$ sequestration level and stability of an ecosystem $[21,22]$. Generally, an increase of F/B indicates improvements in soil $\mathrm{C}$ sequestration capacity and ecosystem stability [23-25]. In the present study, F/B values at sites $\mathrm{H} 1$ and $\mathrm{H} 2$ were significantly higher than those at other sites, indicating that the Korean pine forests at these sites have stronger soil $\mathrm{C}$ sequestration capacity and a higher stability in terms of $\mathrm{C}$ pools. In our previous study, the ratios of labile organic $\mathrm{C}$ to TOC in soils at the two sites were significantly lower than those of other sites. Both of these sets of results proved that the soils at the lower elevations (sites $\mathrm{H} 1$ and $\mathrm{H} 2$ ) had a higher stability in terms of the $\mathrm{C}$ pool and C fixation ability [26].

Table 2 Variability of various microorganism PLFAs at different site

\begin{tabular}{|c|c|c|c|c|c|c|}
\hline \multirow{2}{*}{$\begin{array}{l}\text { Microbial } \\
\text { groups }\end{array}$} & \multicolumn{3}{|l|}{$\mathrm{T}$} & \multicolumn{3}{|l|}{$S$} \\
\hline & Mean $(\mathrm{mmol} / \mathrm{g})$ & Standard deviation & Coefficients of variation (\%) & Mean $(\mathrm{mmol} / \mathrm{g})$ & Standard deviation & Coefficients of variation $(\%$ \\
\hline G+ & 9.05 & 2.61 & 28.78 & 6.50 & 2.29 & 35.28 \\
\hline G- & 14.03 & 5.92 & 42.15 & 9.04 & 2.79 & 30.88 \\
\hline AMF & 1.60 & 0.51 & 31.81 & 0.90 & 0.26 & 28.44 \\
\hline $\mathrm{F}$ & 0.70 & 0.20 & 28.30 & 0.51 & 0.11 & 21.54 \\
\hline Actinomycetes & 4.43 & 1.41 & 31.83 & 3.16 & 1.01 & 32.10 \\
\hline
\end{tabular}




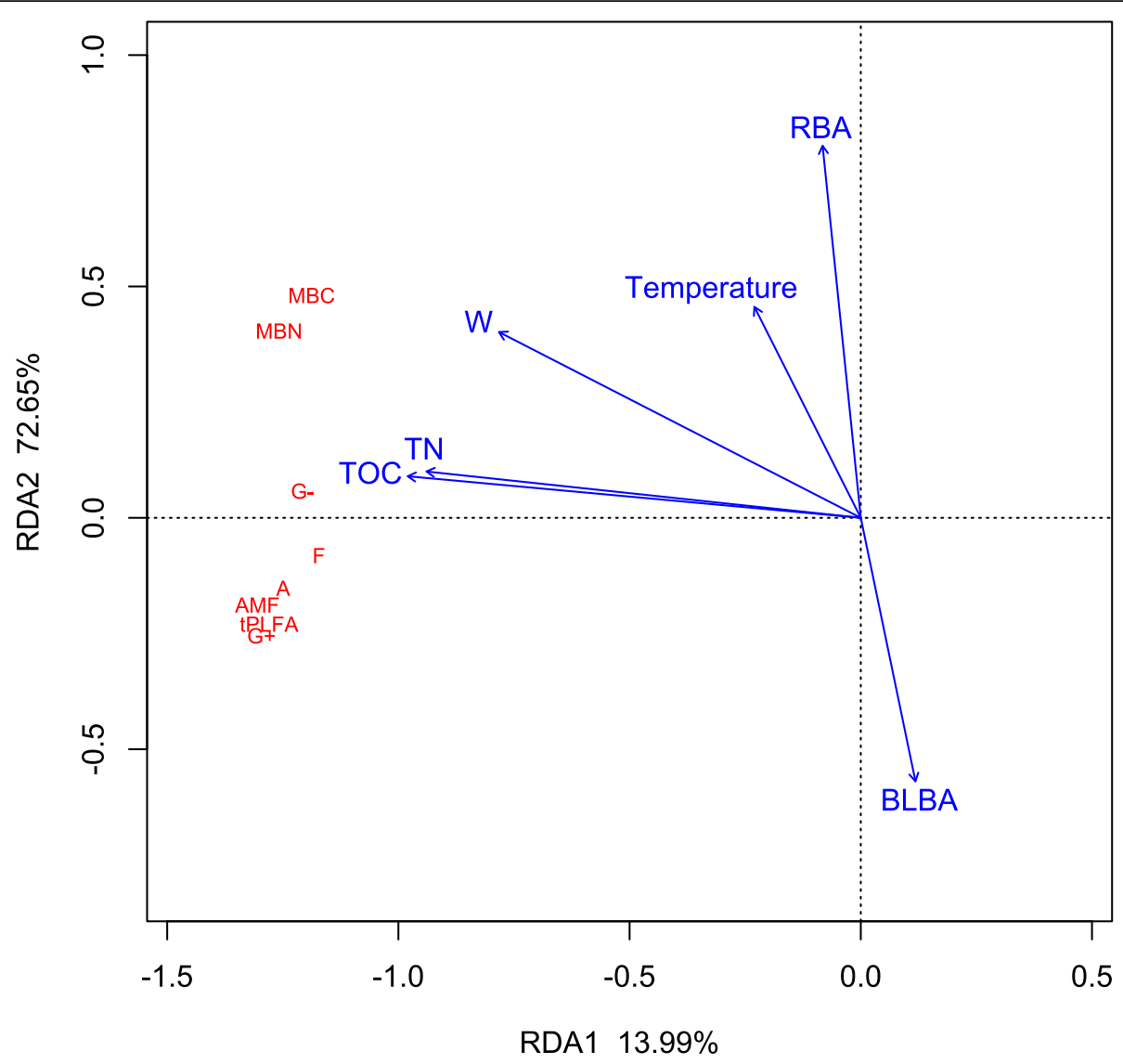

Fig. 5 Redundancy analysis of relationships among soil microbial community structure and soil environmental factors
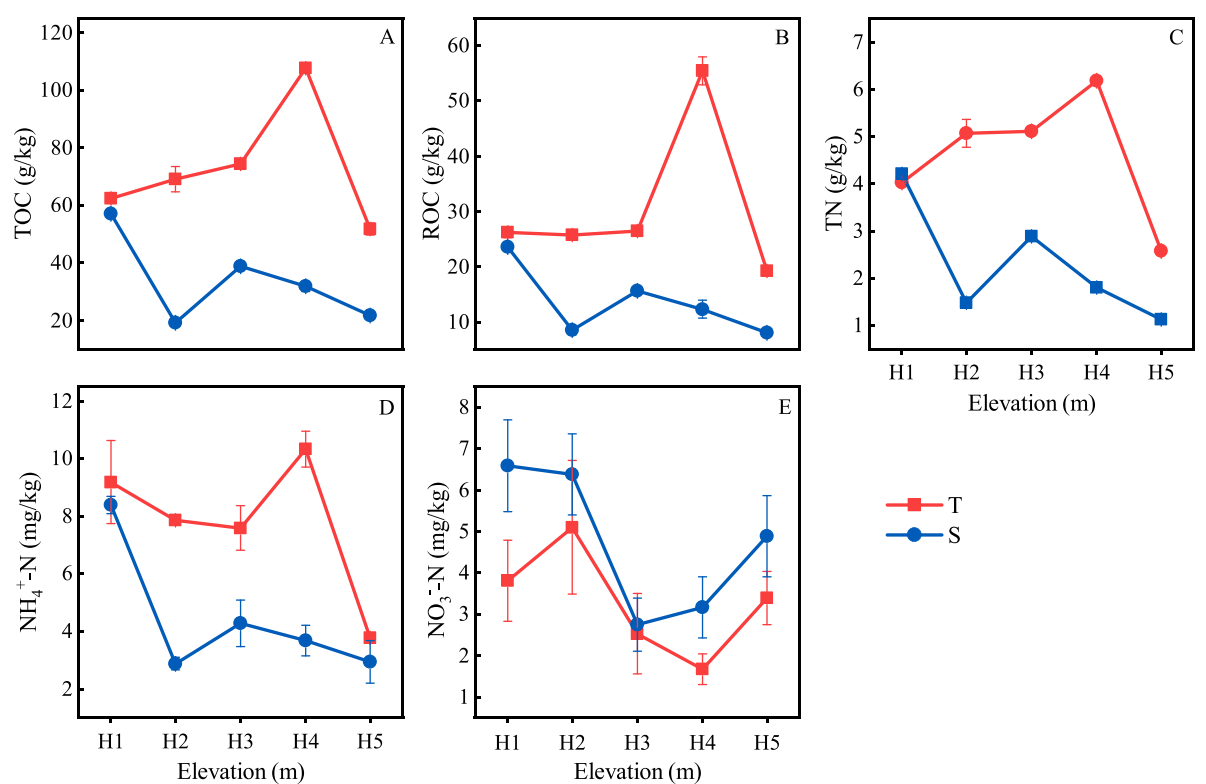

Fig. 6 The variation of soil carbon and nitrogen with elevation. Solid lines and dotted lines represent depths of 0-10 cm and $10-20 \mathrm{~cm}$ respectively 
Table 3 The regression analysis between soil bacterial, fungi and carbon, nitrogen fraction

\begin{tabular}{|c|c|c|c|c|c|c|}
\hline \multirow{3}{*}{$\begin{array}{l}\text { Model } \\
\text { parameter }\end{array}$} & \multicolumn{3}{|l|}{$\mathrm{tB}(\mathrm{y} 1)$} & \multicolumn{3}{|l|}{$\mathrm{tF}\left(\mathrm{y}_{2}\right)$} \\
\hline & \multicolumn{3}{|c|}{$\left(F=103.908, P=0.000, R^{2}=0.780\right)$} & \multicolumn{3}{|c|}{$\left(F=105.169, P=0.000, R^{2}=0.782\right)$} \\
\hline & coefficient & $t$ & $P$ & coefficient & $t$ & $P$ \\
\hline constant & 12.246 & 10.215 & 0.000 & 0.809 & -4.163 & 0.000 \\
\hline $\mathrm{ROC}$ & 0.721 & 10.194 & 0.000 & 0.047 & 10.255 & 0.000 \\
\hline
\end{tabular}

\section{Biogeographical distribution of microbial communities}

The distance-decay relationship is a universal biogeographical model which reflects the spatial distribution pattern of microorganisms. This relationship is used to describe how the similarity of community composition varies with geographical distance [27]. In 1934, Baas-Becking proposed that microorganisms are small in size, large in quantity, short in generation cycle, high in diffusion rate, and that there is no dispersal limitation [28]. However, with the development of biotechnology, more and more studies are supporting the fact that the distribution pattern of microorganisms is affected by deterministic processes, or controlled by some stochastic processes, and that dispersal limitation leads to differences in community structure [29, 30]. Martiny et al. found an overall relationship between geographic distance and community similarity, but no evidence of evolutionary diversification of ammonia-oxidizing bacteria taxa at the continental scale [31]. Zhang et al. observed similar biogeographic patterns for bacterial, archaeal and methanogenic communities along the latitudinal gradient in natural wetlands and anthropogenic paddy fields [32]. In the present study, there was no distance-decay relationship in microbial communities, indicating that the spatial distribution of microbial communities was not regulated by dispersal limitation. In fact, deterministic processes of environmental heterogeneity, and stochastic processes based on diffusion constraints are widely considered as being the main factors driving microbial biogeographic distribution in a variety of environments [33-36]. One previous study showed that the relative contribution of these two processes depends upon the biogeographic-scale [31]. On small spatial scales, deterministic processes based on environmental heterogeneity were frequently reported to exert a greater impact on microbial communities than stochastic processes based on diffusion constraints [37]. Considering the relative consistency of aboveground plant groups, the spatial scale chosen in this study was small (699-1177 m), and environmental factors played a dominant role in influencing the geographical distribution pattern of the microbial community. A partial Mantel Test further demonstrated that environmental factors are indeed the most important factor for the composition of microbial species.

Han et al. [15] and Ping et al. [3] concluded that bacterial and fungal communities showed a distance-decay

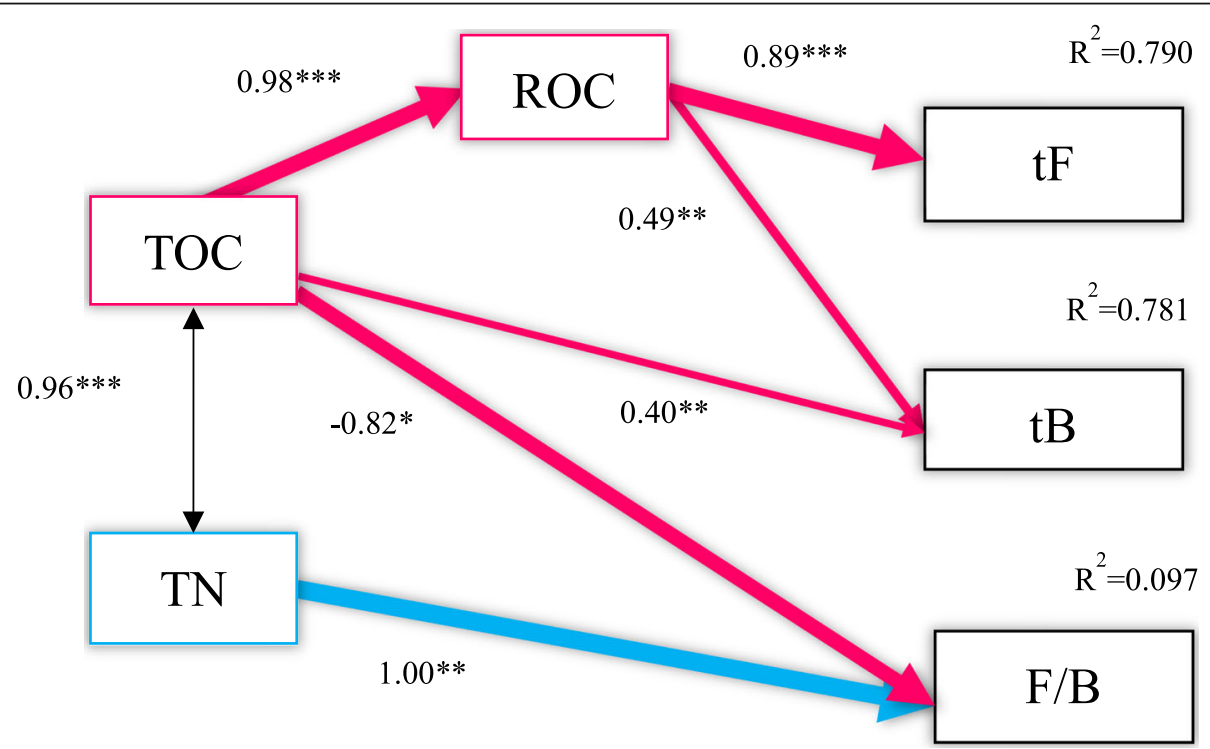

Fig. 7 The relationships between soil microbial community and soil C, N. $X^{2}==1.812 ; \mathrm{DF}=6$; $P=0.936 ; A I C=31.812 ; \mathrm{GFI}=0.980 ; \mathrm{RMSEA}<0.001$; RMSEA $<0.001$. The numbers on the arrow represent the standardized path coefficient, $R^{2}$ represents the amount of interpretation, Significant level: *,$p<0.05 ;{ }^{* *}, p<0.01 ;{ }^{* *}, p<0.001$; and the arrow width represents the strength of significant standardized path coefficients 
Table 4 Effects of soilcarbon, nitrogen components on microbial biomass

\begin{tabular}{lllll}
\hline & & TOC & ROC & TN \\
\hline tB & Direct effect & 0.40 & 0.49 & 0.00 \\
& Indirect effect & 0.48 & 0.00 & 0.00 \\
& Total effect & 0.88 & 0.49 & 0.00 \\
$\mathrm{tF}$ & Direct effect & 0.00 & 0.89 & 0.00 \\
& Indirect effect & 0.87 & 0.00 & 0.00 \\
& Total effect & 0.87 & 0.89 & 0.00 \\
F/B & Direct effect & 0.82 & 0.00 & 1.00 \\
& Indirect effect & 0.00 & 0.00 & 0.00 \\
& Total effect & -0.82 & 0.00 & 1.00 \\
\hline
\end{tabular}

relationship in Korean pine forest of Changbai Mountain. In fact, this conclusion did not quantify the relationship between community similarity and geographical distance. In addition, the difference between their research and this study is that what they selected was the single microbial taxa, i.e. bacteria or fungi, rather than the whole microbial taxa. In fact, it is an indisputable fact that there are differences in the biogeographic distribution patterns of different groups of microorganisms even on the same spatial scale. It is essential to study the whole microbial taxa for a more comprehensive understanding of the microbial ecology of forest ecosystems [16].

A Nonmetric Multidimensional Scaling map showed that the microbial species composition was clearly separated at each site (Fig. 3). It was also evident that changes in elevation do have an effect on the composition of the microbial community. In both soil layers, bacteria exhibited higher CV values, indicating that bacteria were more discrete across elevations (sites). This is obviously related to the different sensitivity of microbial groups to metabolic substrates. It is generally believed that bacteria are more sensitive to soil substrates and environmental changes, whereas fungi are less sensitive [2].

\section{Driving factors of soil microbial community}

The spatial differentiation of microorganisms can be attributed to differences in environmental conditions at different altitudes. Moreover, soil properties and spatial attributes that are associated with altitude can exert strong influences upon the composition of a microbial community [16]. Previous studies have suggested that soil TOC, TN and W are the major factors impacting upon the structure of microbial community [38, 39]. The assimilation efficiency of $\mathrm{C}$ and $\mathrm{N}$ is different among different soil microorganisms, and soil microbial community is modulated by availability and transformation of $\mathrm{C}$ and $\mathrm{N}[40,41]$. Soil water content can affect microbial community structure through $\mathrm{O}_{2}$ availability, substrate diffusion and by altering the water potential within microbial cells [42]. Redundancy analysis also showed that RBA had a significant effect upon the distribution of the soil microbiome in the primary Korean pine forest soil. This confirms our previousprediction that the proportion of coniferous and broad-leaved tree species would have a marked influence upon the soil microbial community. Researchers believed that such an effect was predominantly due to the variety and quality of litter and substrate [43]. In our study, RBA was used to characterize the differences in vegetation composition. Breast-height basal area is known to be an important indicator of the aboveground tree biomass in forest ecosystems [44], while RBA reflected the relative biomass of coniferous and broad-leaved tree species, and is directly related to the proportion of resistant organic matter for soil microbes; consequently, RBA has an important impact upon the structure of soil microbial communities [45]. The RBA at site H5 was clearly higher than at other sites. At this gradient, conifers contain more recalcitrant $\mathrm{C}$, such as lignin, crude fiber, and phenolic substances, since they are difficult to be decomposed by microbes, this therefore limits the further growth of microbes. This may represent a possible factor for why the microbial biomass and distribution of microbes in this area was significantly lower than those at other sites [46]. Some studies have suggested that dominant species in forest ecosystems have profound effects on the soil environment and would have a consistent impact upon the microbial biomass in soil [47, 48]. However, we found that even if the dominant species are the same, the differences accompanying species can have an important impact on the soil microbial tPLFA and each subgroup [49].

\section{Relationship between soil microbial community and carbon and nitrogen}

The structure equation model showed that soil ROC has a significant direct impact upon the biomass of bacteria and fungi. ROC, which is oxidized by $333 \mathrm{mM} \mathrm{KMnO}_{4}$, represents the labile organic $C$ [50]. It is described as the "bio-available" fraction and exhibits high microbial activity and could promote the growth of fungi and bacteria [51]. Multivariate linear regression analysis also obtained similar conclusions (Table 3), indicating that soil ROC was one of the main sources of the microbial-derived $C$ pool. TOC also had a significant indirect effect upon $t B$ and $\mathrm{tF}$ through ROC, which is one of the most active components of TOC, it can be rapidly decomposed by microorganisms and provide a substrate source for its growth and activity [52]. Moreover, there was a significant negative correlation between TOC and F/B. This result indicated that the microorganisms had an effect on the stability of the soil $\mathrm{C}$ pool. This effect might be conferred by changing the contents of the soil TOC with 
a shift in community structures. High TOC could provide an advantage for bacteria to compete with fungi for resources [53]. Bacteria are dominant in the soil of Pinus koraiensis forest, leading to the deposition of microbialderived $\mathrm{C}$ into the TOC reservoir by biomass turnover and necromass accumulation [54].

$\mathrm{N}$ fraction, as an important biogenic element in the process of soil microbial growth, can enhance the ability of microbes to utilize $\mathrm{C}$ sources, and thereby promote an increase in microbial biomass [55]. In the present study, the correlation between TN and the biomass of fungi and bacteria was not significant (Fig. 7). This result also indicated that $\mathrm{C}$ fraction was the main factor influencing soil fungi and bacterial biomass in the primary Korean pine forest of Changbai Mountain. We found a significant positive correlation between soil $\mathrm{TN}$ and $\mathrm{F} / \mathrm{B}$, and the total effect value was 1.00 (Table 4), indicating that microbes can influence $\mathrm{N}$ storage and $\mathrm{N}$ supply potential in the soil via a shift in community structure. Deng et al. further found that F/B was negatively correlated with soil $\mathrm{N}$ mineralization rate [8]. A low $\mathrm{F} / \mathrm{B}$ is unfavorable to $\mathrm{N}$ accumulation in the soil, resulting in the loss of $\mathrm{N}$ and the reduction of $\mathrm{N}$ level [56]. Similar results were also obtained by de Vries et al. [57]. F/B is regarded as an important indicator for evaluating the $\mathrm{C}$ sequestration level in soil. In this study, we found that F/ $\mathrm{B}$ was also closely related to soil $\mathrm{N}$ level.

\section{Conclusion}

In this study, we first investigated the spatial distribution pattern of the soil microbial community across different elevations (sites) in the primary Korean pine broadleaved mixed forest in Changbai Mountain. Our results showed that the TPLFA and PLFAs of soil microbes, including G-, G+, F, AMF, and Actinomycetes, were significantly affected by elevation. F/B ratios were significantly different in the same soil layer at different sites; $\mathrm{F} / \mathrm{B}$ ratios were higher at sites $\mathrm{H} 1$ and $\mathrm{H} 2$, indicating that these areas had higher soil $\mathrm{C}$ sequestration capacity and $\mathrm{C}$ pool stability. Among the microbes investigated in each sub-group, bacteria were more sensitive to the changes of elevation. The similarities of microbial community composition did not show a distance-decay pattern, and environmental heterogeneity was the main factor affecting the geographical distribution pattern of microbial community structure. Soil TOC, TN, W and RBA were the main driving factors for the observed changes in soil microbial biomass in the Korean pine forest in Changbai Mountain. For the Korean pine forest in Changbai Mountain, soil microbial community structure and $\mathrm{C}$ pool stability varied with different elevations, even if the edificator was the same. Furthermore, multiple linear regression analysis and the structure equation model showed that soil ROC was one of the main sources of the microbial-derived $\mathrm{C}$ pool. TOC had a significant direct effect on bacterial biomass and an indirect effect upon bacterial and fungal biomass via ROC. No significant relationship was observed between soil $\mathrm{N}$ fraction and the biomass of fungi and bacteria; $\mathrm{C}$ fraction was identified as the main influential factor upon soil fungi and bacterial biomass in the original Korean pine forest of Changbai Mountain. The effect of microbes on the soil $\mathrm{C}$ pool may be achieved via changes in their own community structure that affect the labile organic $\mathrm{C}$ content in the soil. F/B showed a significant negative correlation with TOC and a significant positive correlation with TN. An increase in F/B promoted the N storage. Our results provide a theoretical basis for analyzing the in-situ ecological function of soil microorganisms in the $\mathrm{C}$ and $\mathrm{N}$ cycle of the Korean pine forest ecosystem.

\section{Methods \\ Study area}

The study was conducted at Changbai Mountain National Nature Reserve in Jilin Province, Northeastern China $\left(41^{\circ} 41^{\prime} 49^{\prime \prime}-42^{\circ} 25^{\prime} 18^{\prime \prime} \mathrm{N}, 127^{\circ} 42^{\prime} 55^{\prime \prime}-128^{\circ} 16^{\prime}\right.$ $\left.48^{\prime \prime} \mathrm{E}\right)$. This area belongs to a temperate continental mountain climate with a long cold winter and a short cool summer. The mean annual temperature varies from 4.9 to $-7.3^{\circ} \mathrm{C}$. The annual period of sunshine is approximately $2300 \mathrm{~h}$ and the frost-free period is only 100 days. Annual relative humidity ranges from 65 to $74 \%$. Precipitation is rich with a mean annual precipitation ranging from 800 and $1800 \mathrm{~mm}$. The soils are dark brown forest soil. The elevation gradient and vegetation composition of each sample site are given in Additional file 1.

\section{Sampling}

We sampled in September 2015. The method of sampling refers to Han et al. [15]. All collected soil samples were sealed and refrigerated and then taken back to the laboratory. Soil samples were then sieved through a 2-mm mesh to eliminate plant residues and roots. We then immediately determined $\mathrm{MBC}$ and $\mathrm{MBN}$. Each homogenized soil sample was divided into two subsamples: one was air-dried to allow the determination of the soil physicochemical properties (Table 5), including TOC, TN, and ROC, while the other sub-sample was stored at $-80{ }^{\circ} \mathrm{C}$ to allow the determination of $\mathrm{NH}_{4}{ }^{+}-\mathrm{N}$, $\mathrm{NO}_{3}{ }^{-}-\mathrm{N}$, and PLFA content.

$\mathrm{T}$ and $\mathrm{S}$ represent depths of $0-10 \mathrm{~cm}$ and $10-20 \mathrm{~cm}$ respectively. Different capital letters in the same column represent significant differences among different elevation gradients at the 0.05 level. Different lowercase letters in the same column represent significant differences 
Table $\mathbf{5}$ Soil properties of the investigated sites

\begin{tabular}{|c|c|c|c|c|c|c|c|c|c|c|c|c|}
\hline $\begin{array}{l}\text { Soil } \\
\text { layer }\end{array}$ & Site & Elevation & $\begin{array}{l}\text { Bulk density } \\
\text { (BD) }\end{array}$ & $\begin{array}{l}\text { Soil water } \\
\text { content }\end{array}$ & $\mathrm{pH}$ & $\begin{array}{l}\text { Soil } \\
\text { temperature }\end{array}$ & Available N & $\begin{array}{l}\text { Available } \\
\text { P }\end{array}$ & Available K & Clay & Silt & Sand \\
\hline$(\mathrm{cm})$ & & (m) & $\left(\mathrm{g} / \mathrm{cm}^{3}\right)$ & (\%) & & $\left({ }^{\circ} \mathrm{C}\right)$ & $(\mathrm{mg} / \mathrm{kg})$ & $(\mathrm{mg} / \mathrm{kg})$ & $(\mathrm{mg} / \mathrm{kg})$ & (\%) & (\%) & (\%) \\
\hline \multirow[t]{5}{*}{$\overline{\mathrm{T}}$} & $\mathrm{H} 1$ & 699 & $\begin{array}{l}1.14 \pm \\
0.09 \mathrm{Aa}\end{array}$ & $\begin{array}{l}38.72 \pm \\
6.54 \mathrm{Aa}\end{array}$ & $\begin{array}{l}6.05 \pm \\
0.01 \mathrm{Aa}\end{array}$ & $\begin{array}{l}13.28 \pm \\
3.23 \mathrm{Aa}\end{array}$ & $\begin{array}{l}407.75 \pm \\
17.6 \mathrm{Aa}\end{array}$ & $\begin{array}{l}68.17 \pm \\
5.7 \mathrm{Aa}\end{array}$ & $\begin{array}{l}488.04 \pm \\
27.3 \mathrm{Aa}\end{array}$ & $\begin{array}{l}27.0 \pm \\
1.9 \mathrm{Aa}\end{array}$ & $\begin{array}{l}43.4 \pm \\
1.2 \mathrm{Aa}\end{array}$ & $\begin{array}{l}29.6 \pm \\
0.8 \mathrm{Aa}\end{array}$ \\
\hline & $\mathrm{H} 2$ & 818 & $\begin{array}{l}0.85 \pm \\
0.03 \mathrm{Ba}\end{array}$ & $\begin{array}{l}32.31 \pm \\
3.89 \mathrm{Ba}\end{array}$ & $\begin{array}{l}5.97 \pm \\
0.04 \mathrm{Ba}\end{array}$ & $\begin{array}{l}12.62 \pm \\
3.10 \mathrm{Ba}\end{array}$ & $\begin{array}{l}418.25 \pm \\
22.7 \mathrm{Ba}\end{array}$ & $\begin{array}{l}53.89 \pm \\
8.6 \mathrm{Aa}\end{array}$ & $\begin{array}{l}403.32 \pm \\
13.7 \mathrm{Ba}\end{array}$ & $\begin{array}{l}16.4 \pm \\
1.3 \mathrm{Ba}\end{array}$ & $\begin{array}{l}43.6 \pm \\
0.7 \mathrm{Aa}\end{array}$ & $\begin{array}{l}40.0 \pm \\
1.4 \mathrm{Ba}\end{array}$ \\
\hline & $\mathrm{H} 3$ & 937 & $\begin{array}{l}0.89 \pm \\
0.09 \mathrm{Ba}\end{array}$ & $\begin{array}{l}44.34 \pm \\
5.69 \mathrm{Ca}\end{array}$ & $\begin{array}{l}6.22 \pm \\
0.03 \mathrm{Ca}\end{array}$ & $\begin{array}{l}12.41 \pm \\
3.37 \mathrm{Ca}\end{array}$ & $\begin{array}{l}530.25 \pm \\
23.3 \mathrm{Ca}\end{array}$ & $\begin{array}{l}54.95 \pm \\
6.5 \mathrm{Ba}\end{array}$ & $\begin{array}{l}1027.08 \pm \\
33.9 \mathrm{Ca}\end{array}$ & $\begin{array}{l}17.8 \pm \\
1.9 \mathrm{BCa}\end{array}$ & $\begin{array}{l}48.7 \pm \\
1.3 \mathrm{Ba}\end{array}$ & $\begin{array}{l}33.5 \pm \\
1.1 \mathrm{Ca}\end{array}$ \\
\hline & $\mathrm{H} 4$ & 1044 & $\begin{array}{l}0.86 \pm \\
0.05 \mathrm{Ba}\end{array}$ & $\begin{array}{l}44.41 \pm \\
6.06 \mathrm{Ca}\end{array}$ & $\begin{array}{l}6.32 \pm \\
0.01 \mathrm{Da}\end{array}$ & $\begin{array}{l}11.38 \pm 3.28 \\
\mathrm{Da}\end{array}$ & $\begin{array}{l}407.75 \pm \\
23.9 \mathrm{Aa}\end{array}$ & $\begin{array}{l}60.24 \pm \\
7.9 \mathrm{Da}\end{array}$ & $\begin{array}{l}678.72 \pm \\
19.4 \mathrm{Da}\end{array}$ & $\begin{array}{l}19.8 \pm \\
1.5 \mathrm{Ca}\end{array}$ & $\begin{array}{l}54.3 \pm \\
0.9 \mathrm{Ca}\end{array}$ & $\begin{array}{l}25.9 \pm \\
1.4 \mathrm{Da}\end{array}$ \\
\hline & H5 & 1177 & $\begin{array}{l}0.99 \pm \\
0.16 \mathrm{ABa}\end{array}$ & $\begin{array}{l}28.14 \pm 2.95 \\
\mathrm{Da}\end{array}$ & $\begin{array}{l}4.95 \pm \\
0.03 \mathrm{Ea}\end{array}$ & $\begin{array}{l}10.86 \pm \\
3.69 \mathrm{Ea}\end{array}$ & $\begin{array}{l}318.50 \pm \\
14.6 \mathrm{Ea}\end{array}$ & $\begin{array}{l}52.31 \pm \\
6.6 \mathrm{Ea}\end{array}$ & $\begin{array}{l}278.88 \pm \\
17.3 \mathrm{Ea}\end{array}$ & $\begin{array}{l}17.7 \pm \\
2.0 \mathrm{BCa}\end{array}$ & $\begin{array}{l}43.1 \pm \\
1.5 \mathrm{Aa}\end{array}$ & $\begin{array}{l}39.2 \pm \\
2.2 \mathrm{Ba}\end{array}$ \\
\hline \multirow[t]{5}{*}{$S$} & $\mathrm{H} 1$ & 699 & $\begin{array}{l}1.33 \pm \\
0.05 \mathrm{Ab}\end{array}$ & $\begin{array}{l}36.31 \pm \\
4.70 A b\end{array}$ & $\begin{array}{l}6.20 \pm \\
0.05 \mathrm{Aa}\end{array}$ & $\begin{array}{l}12.67 \pm \\
3.45 \mathrm{Ab}\end{array}$ & $\begin{array}{l}372.75 \pm \\
15.3 \mathrm{Ab}\end{array}$ & $\begin{array}{l}50.19 \pm \\
3.4 \mathrm{Ab}\end{array}$ & $\begin{array}{l}544.88 \pm \\
18.3 \mathrm{Ab}\end{array}$ & $\begin{array}{l}19.5 \pm \\
1.1 \mathrm{Ab}\end{array}$ & $\begin{array}{l}46.9 \pm \\
1.8 \mathrm{Ab}\end{array}$ & $\begin{array}{l}33.6 \pm \\
0.8 \mathrm{Ab}\end{array}$ \\
\hline & $\mathrm{H} 2$ & 818 & $\begin{array}{l}1.18 \pm \\
0.00 \mathrm{Bb}\end{array}$ & $\begin{array}{l}18.20 \pm \\
6.97 \mathrm{Bb}\end{array}$ & $\begin{array}{l}5.70 \pm \\
0.07 \mathrm{Ba}\end{array}$ & $\begin{array}{l}12.04 \pm \\
3.04 \mathrm{Bb}\end{array}$ & $\begin{array}{l}278.25 \pm \\
15.8 \mathrm{Bb}\end{array}$ & $\begin{array}{l}41.20 \pm \\
2.2 \mathrm{Bb}\end{array}$ & $\begin{array}{l}422.52 \pm \\
10.5 \mathrm{Bb}\end{array}$ & $\begin{array}{l}18.5 \pm \\
1.6 \mathrm{Aa}\end{array}$ & $\begin{array}{l}41.2 \pm \\
0.7 \mathrm{Bb}\end{array}$ & $\begin{array}{l}40.3 \pm \\
2.2 \mathrm{Ba}\end{array}$ \\
\hline & $\mathrm{H} 3$ & 937 & $\begin{array}{l}1.08 \pm \\
0.06 \mathrm{Cb}\end{array}$ & $\begin{array}{l}33.31 \pm \\
8.76 \mathrm{Cb}\end{array}$ & $\begin{array}{l}5.78 \pm \\
0.04 \mathrm{Ba}\end{array}$ & $\begin{array}{l}11.87 \pm \\
3.53 \mathrm{Cb}\end{array}$ & $\begin{array}{l}465.25 \pm \\
20.1 \mathrm{Cb}\end{array}$ & $\begin{array}{l}46.49 \pm \\
5.60 \mathrm{Cb}\end{array}$ & $\begin{array}{l}691.68 \pm \\
21.5 \mathrm{Cb}\end{array}$ & $\begin{array}{l}18.2 \pm \\
0.8 \mathrm{ACa}\end{array}$ & $\begin{array}{l}45.8 \pm \\
1.3 \mathrm{Aa}\end{array}$ & $\begin{array}{l}36.0 \pm \\
0.8 \mathrm{Ab}\end{array}$ \\
\hline & $\mathrm{H} 4$ & 1044 & $\begin{array}{l}1.31 \pm \\
0.05 \mathrm{Ab}\end{array}$ & $\begin{array}{l}16.74 \pm \\
4.04 \mathrm{Db}\end{array}$ & $\begin{array}{l}6.13 \pm \\
0.09 \mathrm{Aa}\end{array}$ & $\begin{array}{l}10.93 \pm \\
3.28 \mathrm{Db}\end{array}$ & $\begin{array}{l}276.50 \pm \\
11.2 \mathrm{Bb}\end{array}$ & $\begin{array}{l}42.79 \pm \\
4.1 \mathrm{Db}\end{array}$ & $\begin{array}{l}252.96 \pm \\
11.6 \mathrm{Db}\end{array}$ & $\begin{array}{l}11.8 \pm \\
1.7 \mathrm{Bb}\end{array}$ & $\begin{array}{l}38.2 \pm \\
2.1 \mathrm{Cb}\end{array}$ & $\begin{array}{l}50.0 \pm \\
1.8 \mathrm{Cb}\end{array}$ \\
\hline & $\mathrm{H} 5$ & 1177 & $\begin{array}{l}1.17 \pm \\
0.07 \mathrm{Bb}\end{array}$ & $\begin{array}{l}17.02 \pm \\
2.07 \mathrm{Db}\end{array}$ & $\begin{array}{l}5.16 \pm \\
0.13 \mathrm{Ca}\end{array}$ & $\begin{array}{l}10.47 \pm \\
4.07 \mathrm{~Eb}\end{array}$ & $\begin{array}{l}162.75 \pm \\
10.7 \mathrm{~Eb}\end{array}$ & $\begin{array}{l}17.41 \pm \\
2.7 \mathrm{~Eb}\end{array}$ & $\begin{array}{l}164.64 \pm \\
14.8 \mathrm{~Eb}\end{array}$ & $\begin{array}{l}15.0 \pm \\
2.9 \mathrm{BCa}\end{array}$ & $\begin{array}{l}37.4 \pm \\
1.8 \mathrm{Cb}\end{array}$ & $\begin{array}{l}47.6 \pm \\
1.2 \mathrm{Cb}\end{array}$ \\
\hline
\end{tabular}

among different layers at the 0.05 level. Soil water content and Temperature were the average of the whole of grow season (May-Oct).

\section{Composition of tree species in experimental areas}

Within the sample plots at each site, we recorded the different types of each living tree species present and determined the diameter at breast height $(\mathrm{DBH})(\geq 5$ $\mathrm{cm}$ ) for each tree. The CBA (Eq. 1), BLBA (Eq. 2) and RBA (Eq. 3) were also calculated. The derivation of these parameters is shown below.

$$
\begin{aligned}
& \mathrm{CBA}=\pi \times\left(\frac{\mathrm{DBH}_{\mathrm{CBA}}}{2}\right)^{2} \\
& \mathrm{BLBA}=\pi \times\left(\frac{\mathrm{DBH}_{\mathrm{BLBA}}}{2}\right)^{2} \\
& \mathrm{RBA}=\frac{\mathrm{CBA}}{\mathrm{BLBA}}
\end{aligned}
$$

\section{Analysis of $\mathrm{C}$ and $\mathrm{N}$ components in soil samples}

TN and TOC were measured in soil samples by a EuroEA3000 element analyzer (Leeman company, America) while ROC was determined by $333 \mathrm{mM} \mathrm{KMnO}{ }_{4}$ oxidation [50]. In brief, air-dried soil, containing approximately $15 \mathrm{mg}$ of $\mathrm{C}$, was placed in a $50-\mathrm{mL}$ centrifuge tube and $25 \mathrm{~mL}$ of $0.333 \mathrm{M} \mathrm{KMnO}_{4}$ solution was added; the mixture was then shaken at $120 \mathrm{rpm}$ for $1 \mathrm{~h}$.
After centrifugation, the supernatant was diluted by a factor of 1:250 with sterile water. A blank experiment, without soil, was treated in a similar manner. The absorbance of the diluted solution was then measured at $565 \mathrm{~nm}$, and the ROC was then calculated according to the absorbance. $\mathrm{NH}_{4}{ }^{+}-\mathrm{N}$ was analyzed using the indophenol blue colorimetric method. Fresh soil samples were extracted with $2 \mathrm{M} \mathrm{KCl}$ solution. Then, $10 \mathrm{~mL}$ of the extract was mixed with $5 \mathrm{~mL}$ of phenol solution, and $5 \mathrm{~mL}$ of sodium hypochlorite alkaline solution at room temperature for $1 \mathrm{~h}$. The $\mathrm{NH}_{4}{ }^{+}-\mathrm{N}$ concentration in the extracted solutions was then determined at an absorbance of $625 \mathrm{~nm}$. $\mathrm{NO}_{3}{ }^{-}-\mathrm{N}$ was determined by the phenol disulfonic acid method. In brief, fresh soil samples were extracted with distilled water and then evaporated until they were fully dry. Then, $2 \mathrm{~mL}$ of phenol disulfonic acid reagent was added quickly and incubated for $10 \mathrm{~min}$, followed by $20 \mathrm{~mL}$ of distilled water and excess $(1: 1)$ of ammonium hydroxide. The absorbance of the solution was then measured at a wavelength of $420 \mathrm{~nm}$. MBC and MBN were estimated using the fumigation-extraction method [58]. In brief, fresh soil samples were fumigated with ethanol-free chloroform for $24 \mathrm{~h}$ in the dark at $25^{\circ} \mathrm{C}$. Fumigated soil was then extracted with $\mathrm{K}_{2} \mathrm{SO}_{4}$ solution; non-fumigated soil was treated in the same way. MBC and MBN were then determined using an Elementar Vario Max element analyzer (Elementar, Germany) according to the differences in $\mathrm{C}$ and $\mathrm{N}$ content between fumigated soil and 
non-fumigated soil with an internal conversion coefficient of 0.45 .

\section{Analysis of phospholipid fatty acids in soil samples}

Soil microbial community structure was analyzed using PLFAs as described previously [59]. In brief, $8 \mathrm{~g}$ of fresh soil was extracted with a liquid mixture of chloroform: methanol: phosphate buffer (1:2:0.8 by volume) for $2 \mathrm{~h}$. After centrifugation, the supernatant was transferred to a separatory funnel and mixed with $12 \mathrm{~mL}$ of chloroform and $12 \mathrm{~mL}$ of phosphate buffer for $2 \mathrm{~min}$. The lower phase was then collected and extracted with $23 \mathrm{~mL}$ of the liquid mixture for $30 \mathrm{~min}$. After centrifugation, the separated mixture was allowed to rest overnight. The lower phase was then concentrated by $\mathrm{N}_{2}$ at a temperature of $30-32{ }^{\circ} \mathrm{C}$ and used in lipid fractionation. The concentrated lipid extract was dissolved in $200 \mu \mathrm{L}$ of chloroform and fractionated from other lipids on solid phase extraction columns (Supelco Inc., Bellefonte, PA). Neutral and glycol lipids were eluted by $5 \mathrm{~mL}$ of $\mathrm{CHCl}_{3}$ and $10 \mathrm{~mL}$ of acetone; polar lipids were then eluted by 5 $\mathrm{mL}$ of methanol, respectively. The methanol phase was then collected and dried under $\mathrm{N}_{2}$ at a temperature of $30-32^{\circ} \mathrm{C}$. The dried lipids were then mixed with $1 \mathrm{~mL}$ of a 1:1 solution of methanol and toluene and $1 \mathrm{~mL}$ of 0.2 $\mathrm{mol} / \mathrm{L}$ potassium hydroxide, heated at $37^{\circ} \mathrm{C}$ for $15 \mathrm{~min}$, then dried under $\mathrm{N}_{2}$ after extraction with $\mathrm{n}$-hexane. Finally, fatty acid methyl esters were detected by gas chromatography-mass spectrometry (Agilent 6850 series Gas Chromatograph) equipped with an HP-5 capillary column $(25.0 \mathrm{~m} \times 200 \mathrm{~mm} \times 0.33 \mathrm{~mm})$ with $\mathrm{N}_{2}$ as the carrier gas. Concentrations of each PLFA were calculated based on the 19:0 internal standard concentrations and abundances were expressed as nmol per gram dry soil. The PLFAs used as biomarkers are shown in Table 6. F, AMF were generally attributed to $\mathrm{tF}[65]$, and $\mathrm{tB}$ was calculated as the sum of G+, G-, and Actinomycetes biomarkers together with 10:0; 13:0; 16:0, and 20:0 [59, 66]. PLFAs not assigned as biomarkers were included in total PLFA (tPLFA) yields.

\section{Statistical analyses}

One-way analysis of variance was used to determine the effects of elevations (sites) on soil physicochemical properties, $\mathrm{C}$ and $\mathrm{N}$ fractions, microbial biomass, and microbial PLFAs. The significance level was set to $p<0.05$. Statistical analysis was conducted in SPSS 19.0 for Windows. Nonmetric Multidimensional Scaling was used to visualize the overall differences in microbial community dissimilarities across different elevations (sites)(www. omicshare.com/tools/). Using $\mathrm{R}$ studio, we used the Mantel test and the Partial Mantel test, to determine correlations between environmental variability and geographic distance and the variation of microbial community. Ordination was used to analyze the relationship between the composition of soil microbial community and soil environmental factors. Detrended correspondence analysis was performed for microbial PLFAs to determine whether the community was ranked by a unimodal model or a linear model. The statistical significance of the redundancy analysis was tested using the Monte Carlo permutation test (499 permutations; $p<$ 0.05).

The relationships between microbial biomass, microbial community structure, and the $\mathrm{C}$ and $\mathrm{N}$ components in soil were analyzed using multivariate linear regression analysis by SPSS 19.0 and the structure equation model by Amos 21.0 software. Multivariate linear regression analysis was performed stepwise method which selected $\mathrm{tB}, \mathrm{tF}$ and $\mathrm{F} / \mathrm{B}$ as dependent variables and soil TOC, ROC, TN, $\mathrm{NH}_{4}{ }^{+}-\mathrm{N}$ and $\mathrm{NO}_{3}{ }^{-}-\mathrm{N}$ as independent variables. We started a priori model based on a literature review and our knowledges. The utilization and transformation of organic $\mathrm{C}$ and $\mathrm{N}$ by microorganisms is generally thought to mainly include the dominant pathways of fungi and bacteria [67]. Therefore, the fungal biomass and bacterial (tF, tB) and $\mathrm{F} / \mathrm{B}$ were selected to represent indices of the soil microbial community structure. Moreover, soil labile organic $\mathrm{C}$ and inorganic $\mathrm{N}$ were considered to provide $\mathrm{C}$ source and $\mathrm{N}$ source for microbial metabolization, respectively, which may impact upon microbial biomass $[68,69]$. Previous studies have also

Table 6 Phospholipid fatty acids (PLFAs) used as biomarkers

\begin{tabular}{|c|c|c|c|}
\hline Microbial group & Fattyacidtype & Phospholipids fatty acid signatures & Reference \\
\hline Gram-positive bacteria & a-/I-branched fatty acids & $\begin{array}{l}\text { 12:0 iso, } 13: 0 \text { iso, } 13: 0 \text { anteiso, } 14: 0 \text { iso, } 15: 0 \text { iso, } 15: 0 \text { anteiso, } \\
\text { 16:0 iso, } 16: 0 \text { anteiso, } 17: 0 \text { iso, } 17: 0 \text { anteiso, } 18: 0 \text { iso, } 19: 0 \text { iso, } \\
\text { 19:0 anteiso, } 20: 0 \text { iso }\end{array}$ & {$[60,61]$} \\
\hline Gram-negative bacteria & $\begin{array}{l}\text { monounsaturated fatty acids } \\
\text { and cyclopropane fatty acids }\end{array}$ & 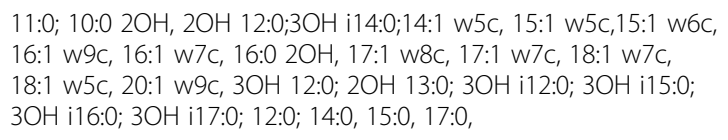 & {$[2,61,62]$} \\
\hline Actinomycetes & Methyl branched fatty acids & 16:0 10-methyl, 17:0 10-methyl, 18:0 10-methyl & [60] \\
\hline Fungi & & $18: 2 w 6 c, 18: 2 w 9 c$ & [63] \\
\hline Arbuscular mycorrhizal fungi & & $16: 1 w 5 c$ & [64] \\
\hline
\end{tabular}


found that the ratio of fungi to bacteria may affect the storage of soil $\mathrm{C}$ and $\mathrm{N}$ [8]. Then, the relationship between soil microbial community structure and soil $\mathrm{C}$ and $\mathrm{N}$ components was established. In order to get the most parsimonious model, the paths and indicators which were not significant were deleted. The adequacy of the model was determined by non-significant $x^{2}$ tests $(P>0.05)$, goodness-of-fit $(\mathrm{GFI} \geq 0.90)$ and root square mean error of approximation $($ RMSEM $<0.1$ ). Moreover, Akaike information criterion (AIC) was used to determine the model that was the most parsimonious with the data [70].

\section{Additional files}

Additional file 1: Vegetation distribution of the sampling areas. (DOCX 19 kb)

Additional file 2: Correction between tPLFA and MBC. (PNG 13 kb)

\section{Abbreviations}

AIC: Akaike information criterion; AMF: Arbuscular mycorrhizal fungi; BLBA: Breast-height basal area of broad-leaved tree species per unit area; C: Carbon; CBA: Breast-height basal area of coniferous trees species per unit area; F: Fungi; F/B: Ratio of fungal PLFAs to bacterial PLFAs; G-: Gramnegative bacteria; G+: Gram-positive bacteria; GFI: Goodness-of-fit; MBC: Microbial biomass carbon; MBN: Microbial biomass nitrogen; N: Nitrogen; PLFA: Phospholipid fatty acid; RBA: Ratio of breast-height basal area of coniferous trees to that of broad-leaved tree species; RMSEM: Root square mean error of approximation; ROC: Readily oxidized organic carbon; tB: Bacterial biomass; tF: Fungal biomass; TN: Total nitrogen; TOC: Total organic carbon; tPLFA: Total PLFAs; W: Soil water content

\section{Acknowledgments}

We thank Lifen Jiang from Northern Arizona University and Xin Jing from Peking University for support and expertise in statistical analysis. We thank Wenjie Yu and Liwu Qin for helping with sampling.

\section{Authors' contributions}

FFJ and LMH designed the project. LMH carried out the experiments. SX, $\mathrm{LMH}, \mathrm{HYB}$ and FFJ participated in the data analysis and wrote the manuscript. All authors read and approved the final manuscript.

\section{Funding}

This research was supported by grants from National Natural Science Foundation of China (31670496), which supported preparation of test materials, and the Fundamental Research Funds for the Central Universities (2572015EA02), which supported laboratory analysis. Both of above supported the writing and publishing of papers.

\section{Availability of data and materials}

All data generated or analyzed during this study are included in this published article and its supplementary information files. The raw data are available from the corresponding author on reasonable request.

\section{Ethics approval and consent to participate}

Sampling permission has been obtained for Changbai Mountain National Nature Reserve in Jilin Province, Northeastern China and field studies were conducted in accordance with local legislation.

\section{Consent for publication}

Not applicable.

\section{Competing interests}

The authors declare that they have no competing interests.

\section{Author details}

${ }^{1}$ College of Life Science, Northeast Forestry University, Harbin 150040, China.

${ }^{2}$ College of Life Science, Heilongjiang University, Harbin 150080, China.

${ }^{3}$ Northeast Forestry University, Harbin 150040, China.

Received: 23 November 2018 Accepted: 28 August 2019

Published online: 13 September 2019

\section{References}

1. Grosso F, lovieno P, Alfani A, De Nicola F. Structure and activity of soil microbial communities in three Mediterranean forests. Appl Soil Ecol. 2018; 130:280-7.

2. Dong W, Zhang X, Dai X, Fu X, Yang F, Liu X, Sun X, Wen X, Schaeffer S. Changes in soil microbial community composition in response to fertilization of paddy soils in subtropical China. Appl Soil Ecol. 2014;84:140-7.

3. Ping Y, Han D, Wang N, Hu Y, Mu L, Feng F. Vertical zonation of soil fungal community structure in a Korean pine forest on Changbai Mountain, China. World J Microbiol Biotechnol. 2017:33.

4. Tu Q, Deng Y, Yan Q, Shen L, Lin L, He Z, Wu L, Van NJ, Buzzard V, Michaletz ST. Biogeographic patterns of soil Diazotrophic communities across Six forests in the North America. Mol Ecol. 2016;25:2937-48.

5. Rutigliano FA, D'Ascoli R, Virzo De Santo A. Soil microbial metabolism and nutrient status in a Mediterranean area as affected by plant cover. Soil Biol Biochem. 2004;36:1719-29.

6. Delmont TO, Prestat E, Keegan KP, Faubladier M, Robe P, Eric IMC, Le Paslier D, Simonet $P$, Vogel TM. Structure, fluctuation and magnitude of a natural grassland soil metagenome. ISME J. 2012;6:1677-87.

7. Bailey VL, Smith JL, Bolton H. Fungal-to-bacterial ratios in soils investigated for enhanced C sequestration. Soil Biol Biochem. 2002;34:997-1007.

8. Deng Q, Cheng X, Hui D, Zhang Q, Li M, Zhang Q. Soil microbial community and its interaction with soil carbon and nitrogen dynamics following afforestation in Central China. Sci Total Environ. 2016;541:230-7.

9. Liu Y, Wei X, Guo X, Niu D, Zhang J, Gong X, Jiang Y. The long-term effects of reforestation on soil microbial biomass carbon in sub-tropic severe red soil degradation areas. Forest Ecol Manag. 2012;285:77-84.

10. Zhang J, Han S, Yu G. Seasonal variation in carbon dioxide exchange over a 200-year-old Chinese broad-leaved Korean pine mixed forest. Agric For Meteorol. 2006;137:150-65.

11. Wu J, Guan D, Zhang M, Han S, Yu G, Sun X. Carbon budget characteristics of the broadleaved Korean pine forests in Changbaishan Mountains. J Beijing Forestry Univ. 2007:29:1-6.

12. He HS, Hao Z, Mladenoff DJ, Shao G, Hu Y, Chang Y. Simulating forest ecosystem response to climate warming incorporating spatial effects in North-Eastern China. J Biogeogr. 2005;32:2043-56.

13. Thoms C, Gattinger A, Jacob M, Thomas FM, Gleixner G. Direct and indirect effects of tree diversity drive soil microbial diversity in temperate deciduous forest. Soil Biol Biochem. 2010;42:1558-65.

14. Ren C, Zhang W, Zhong Z, Han X, Yang G, Feng Y, Ren G. Differential responses of soil microbial biomass, diversity, and compositions to altitudinal gradients depend on plant and soil characteristics. Sci Total Environ. 2018;610-611:750-8.

15. Han D, Wang N, Sun X, Hu Y, Feng F. Biogeographical distribution of bacterial communities in Changbai Mountain, Northeast China. Microbiol Open. 2018;7:e529.

16. Cui $Y$, Bing $H$, Fang $L$, Wu $Y, Y u$ J, Shen $G$, Jiang $M$, Wang $X$, Zhang $X$. Diversity patterns of the rhizosphere and bulk soil microbial communities along an altitudinal gradient in an alpine ecosystem of the eastern Tibetan plateau. GEODERMA. 2019;338:118-27.

17. Feng Y, Motta AC, Reeves DW, Burmester CH, van Santen E, Osborne JA. Soil microbial communities under conventional-till and no-till continuous cotton systems. Soil Biol Biochem. 2003;35:1693-703.

18. Frostegård $\AA$, Bååth $E$, Tunlid A. Shifts in the structure of soil microbial communities in limed forests as revealed by phospholipid fatty acid analysis. Soil Biol Biochem. 1993;6:723-30.

19. Strickland MS, Rousk J. Considering fungal:bacterial dominance in soilsmethods, controls, and ecosystem implications. Soil Biol Biochem. 2010;42: 1385-95.

20. Ingwersen J, Poll C, Streck T, Kandeler E. Micro-scale modelling of carbon turnover driven by microbial succession at a biogeochemical interface. Soil Biol Biochem. 2008;40:864-78. 
21. Malik AA, Chowdhury S, Schlager V, Oliver A, Puissant J, Vazquez PGM, Jehmlich N, von Bergen M, Griffiths Rl, Gleixner G. Soil fungal:bacterial ratios are linked to altered carbon cycling. Front Microbiol. 2016;7:1247.

22. Yergeau E, Bokhorst S, Kang S, Zhou J, Greer CW, Aerts R, Kowalchuk GA Shifts in soil microorganisms in response to warming are consistent across a range of Antarctic environments. ISME J. 2012;6:692-702.

23. Bardgett RD, Jones AC, Jones DL, Kemmitt SJ, Cook R, Hobbs PJ. Soil microbial community patterns related to the history and intensity of grazing in sub-montane ecosystems. Soil Biol Biochem. 2001;33:1653-64.

24. Wang N, Yang X, Li S, Wang N, Han D, Feng F. Seasonal dynamics of soil microbial biomass carbon-nitrogen in the Korean pine mixed forests along elevation gradient. Scientia Silvae Sinicae. 2016;52:150-8.

25. Boyle SA, Yarwood RR, Bottomley PJ, Myrold DD. Bacterial and fungal contributions to soil nitrogen cycling under Douglas fir and red alder at two sites in Oregon. Soil Biol Biochem. 2008;40:443-51.

26. Liu M, Sun X, Yu W, Qin L, Feng F. Seasonal dynamics of soil active organic carbon in the original Pinus koraiensis forest in Changbai Mountain, China. J Nanjing Forestry University (Natural Science Edition). 2018;42:67-74.

27. Hanson CA, Fuhrman JA, Horner-Devine MC, Martiny JBH. Beyond biogeographic patterns: processes shaping the microbial landscape. Nat Rev Microbiol. 2012:10:497-506.

28. M BLG: Geobiologie; of inleiding tot de milieukunde. WP Van Stockum and Zoon NV 1934

29. Jizhong Z, Sanghoon K, Schadt CW, Garten CT. Spatial scaling of functional gene diversity across various microbial taxa. P Natl Acad Sci USA. 2008;105:7768-73.

30. Whitaker RJ, Grogan DW, Taylor JW. Geographic barriers isolate endemic populations of hyperthermophilic archaea. SCIENCE. 2003;301:976-8.

31. Martiny JB, Eisen JA, Penn K, Allison SD, Horner-Devine MC. Drivers of bacterial beta-diversity depend on spatial scale. Proc Natl Acad Sci U S A. 2011:108:7850-4

32. Zhang J, Jiao S, Lu Y. Biogeographic distribution of bacterial, archaeal and methanogenic communities and their associations with methanogenic capacity in Chinese wetlands. Sci Total Environ. 2018; 622-623:664-75

33. Bokulich NA, Thorngate JH, Richardson PM, Mills DA. Microbial biogeography of wine grapes is conditioned by cultivar, vintage, and climate. P Natl Acad Sci USA. 2014;111:E139.

34. Lindström ES, Langenheder S. Local and regional factors influencing bacterial community assembly. Env Microbiol Rep. 2012;4:1-9.

35. Lear G, Bellamy J, Case BS, Lee JE, Buckley HL. Fine-scale spatial patterns in bacterial community composition and function within freshwater ponds. ISME J. 2014;8:1715-26.

36. Ranjard L, Dequiedt S, Prévost-Bouré NC, Thioulouse J, Saby NPA, Lelievre M, Maron PA, Morin FER, Bispo A, Jolivet C. Turnover of soil bacterial diversity driven by wide-scale environmental heterogeneity. Nat Commun. 2013:4:1434.

37. Wang K, Ye X, Chen H, Zhao Q, Hu C, He J, Qian Y, Xiong J, Zhu J, Zhang D. Bacterial biogeography in the coastal waters of northern Zhejiang, East China Sea is highly controlled by spatially structured environmental gradients. Environ Microbiol. 2015;17:3898-913.

38. Chen $\mathrm{H}$, Zhao X, Lin Q, Li G, Kong W. Using a combination of PLFA and DNA-based sequencing analyses to detect shifts in the soil microbial community composition after a simulated spring precipitation in a semiarid grassland in China. Sci Total Environ. 2019;657:1237-45.

39. Luo S, Wang S, Tian L, Shi S, Xu S, Yang F, Li X, Wang Z, Tian C. Aggregaterelated changes in soil microbial communities under different ameliorant applications in saline-sodic soils. Geoderma. 2018;329:108-17.

40. Zhang L, Jing Y, Xiang Y, Zhang R, Lu H. Responses of soil microbial community structure changes and activities to biochar addition: a metaanalysis. Sci Total Environ. 2018;643:926-35.

41. Shao P, Liang C, Rubert-Nason K, Li X, Xie H, Bao X. Secondary successional forests undergo tightly-coupled changes in soil microbial community structure and soil organic matter. Soil Biol Biochem. 2019;128:56-65.

42. Ahmed IU, Mengistie HK, Godbold DL, Sandén H. Soil moisture integrates the influence of land-use and season on soil microbial community composition in the Ethiopian highlands. Appl Soil Ecol. 2019;135:85-90.

43. Xu X, Thornton PE, Post WM. A global analysis of soil microbial biomass carbon, nitrogen and phosphorus in terrestrial ecosystems. Glob Ecol Biogeogr. 2013;22:737-49.

44. Alvarez E, Duque A, Saldarriaga J, Cabrera K, de Las Salas G, Del Valle I, Lema A, Moreno F, Orrego S, Rodríguez L. Tree above-ground biomass allometries for carbon stocks estimation in the natural forests of Colombia. Forest Ecol Manag. 2012;267:297-308

45. Zhang $P$, Tian X, He X, Song F, Ren L, Jiang P. Effect of litter quality on its decomposition in broadleaf and coniferous forest. Eur J Soil Biol. 2008:44:392-9.

46. Xu Z, Yu G, Zhang X, Ge J, He N, Wang Q, Wang D. The variations in soil microbial communities, enzyme activities and their relationships with soil organic matter decomposition along the northern slope of Changbai Mountain. Appl Soil Ecol. 2015;86:19-29.

47. Saetre $P$, Bååth E. Spatial variation and patterns of soil microbial community structure in a mixed spruce-birch stand. Soil Biol Biochem. 2000;32:909-17.

48. Snajdr J, Merhautova W. Activity and spatial distribution of lignocellulosedegrading enzymes during forest soil colonization by saprotrophic basidiomycetes. Enzyme Microbial Technol. 2008:43:186-92.

49. Prober SM, Leff JW, Bates ST, Borer ET, Firn J, Harpole WS, Lind EM, Seabloom EW, Adler PB, Bakker JD. Plant diversity predicts beta but not alpha diversity of soil microbes across grasslands worldwide. Ecol Lett. 2015; 18:85-95.

50. Blair GJ, Lefroy R, Lisle L. Soil carbon fractions based on their degree of oxidation, and the development of a carbon management index for agricultural systems. Aust J Agric Res. 1995;46:393-406.

51. Xiao Y, Huang Z, Lu X. Changes of soil labile organic carbon fractions and their relation to soil microbial characteristics in four typical wetlands of Sanjiang plain, Northeast China. Ecol Eng. 2015;82:381-9.

52. Li Z, Zhao B, Zhang J. Effects of maize residue quality and soil water content on soil labile organic carbon fractions and microbial properties. Pedosphere. 2016;26:829-38.

53. Jiang $Y$, Qian H, Wang X, Chen L, Liu M, Li H, Sun B. Nematodes and microbial community affect the sizes and turnover rates of organic carbon pools in soil aggregates. Soil Biol Biochem. 2018;119:22-31.

54. Benner R. Biosequestration of carbon by heterotrophic microorganisms. Nat Rev Microbiol. 2011;9:75

55. Demoling F, Ola Nilsson L, Bååth E. Bacterial and fungal response to nitrogen fertilization in three coniferous forest soils. Soil Biol Biochem. 2008; 40:370-9.

56. de Vries FT, van Groenigen JW, Hoffland E, Bloem J. Nitrogen losses from two grassland soils with different fungal biomass. Soil Biol Biochemi. 2011; 43:997-1005.

57. de Vries FT, Hoffland E, van Eekeren N, Brussaard L, Bloem J. Fungal/ bacterial ratios in grasslands with contrasting nitrogen management. Soil Biol Biochem. 2006;38:2092-103.

58. Vance ED, Brookes PC, Jenkinson DS. An extraction method for measuring soil microbial biomass C. Soil Biol Biochem. 1987;19:703-7.

59. Bossio DA, Scow KM. Impacts of carbon and flooding on soil microbial communities: phospholipid fatty acid profiles and substrate utilization patterns. Microb Ecol. 1998:35:265-78.

60. Bossio DA, Fleck JA, Scow KM, Fujii R. Alteration of soil microbial communities and water quality in restored wetlands. Soil Biol Biochem. 2006;38:1223-33.

61. Yao X, Zhang N, Zeng H, Wang W. Effects of soil depth and plant-soi interaction on microbial community in temperate grasslands of northern China. Sci Total Environ. 2018:630:96-102.

62. Kourtev PS, Ehrenfeld JG, Häggblom M. Exotic plant species alter the microbial community structure and function in the soil. Ecology. 2002:83:3152-66.

63. Bååth $\mathrm{E}$, Anderson TH. Comparison of soil fungal/bacterial ratios in a $\mathrm{pH}$ gradient using physiological and PLFA-based techniques. Soil Biol Biochem. 2003;35:955-63.

64. Kaiser C, Koranda M, Kitzler B, Fuchslueger L, Schnecker J, Schweiger P, Rasche F, Zechmeister-Boltenstern S, Sessitsch A, Richter A. Belowground carbon allocation by trees drives seasonal patterns of extracellular enzyme activities by altering microbial community composition in a beech forest soil. New Phytol. 2010;187:843-58.

65. Sun B, Jia S, Zhang S, McLaughlin NB, Zhang X, Liang A, Chen X, Wei S, Liu S. Tillage, seasonal and depths effects on soil microbial properties in black soil of Northeast China. Soil Tillage Res. 2016;155:421-8.

66. Liu D, Huang Y, Sun H, An S. The restoration age of Robinia pseudoacacia plantation impacts soil microbial biomass and microbial community structure in the loess plateau. Catena. 2018;165:192-200.

67. Six J, Frey SD, Thiet RK, Batten KM. Bacterial and fungal contributions to carbon sequestration in agroecosystems. Soil Sci Soc Am J. 2006;70:555-69. 
68. Huang X, Liu S, Wang H, Hu Z, Li Z, You Y. Changes of soil microbial biomass carbon and community composition through mixing nitrogenfixing species with Eucalyptus urophylla in subtropical China. Soil Biol Biochem. 2014:73:42-8.

69. Tian D, Jiang L, Ma S, Fang W, Schmid B, Xu L, Zhu J, Li P, Losapio G, Jing X, et al. Effects of nitrogen deposition on soil microbial communities in temperate and subtropical forests in China. Sci Total Environ. 2017;607-608: 1367-75.

70. Milcu A, Allan E, Roscher C, Eienhauer N. Functionally and phylogenetically diverse plant communities key to soil biota. Ecology. 2013;94:1878-85.

\section{Publisher's Note}

Springer Nature remains neutral with regard to jurisdictional claims in published maps and institutional affiliations.

Ready to submit your research? Choose BMC and benefit from:

- fast, convenient online submission

- thorough peer review by experienced researchers in your field

- rapid publication on acceptance

- support for research data, including large and complex data types

- gold Open Access which fosters wider collaboration and increased citations

- maximum visibility for your research: over $100 \mathrm{M}$ website views per year

At BMC, research is always in progress.

Learn more biomedcentral.com/submissions 